\title{
To KNOW OR Not TO KNOW?
}

\section{ThE PRIVACY LAW IMPLICATIONS OF THE 1996 PAEDOPHILE AND SEX OFFENDER INDEX}

\author{
Jae Lemin *
}

This paper reflects on the privacy and public interest issues raised by the publication of an index of paedophiles and sex offenders. The legislation and caselaw of other jurisdictions is investigated to assess the relevance of that experience to any reform of the law in New Zealand.

\section{INTRODUCTION}

A man is released from prison after serving three years of a four year sentence for the rape of a ten year old girl. While in prison he refused all rehabilitative treatment and at the time of his release was still having violent sexual fantasies about children. ${ }^{1}$ Arguably, members of the community have a strong right to know if this man is amongst them so that adequate precautions can be taken. Another man is convicted of indecent assault at a party in 1985. When the assault occurred both he and the complainant were very intoxicated. Since his probation period ended he has not reoffended but has lived a successful and productive life. Claims of a right to know the movements of this man appear less persuasive.

Paedophilia and sex offending are major community issues in the 1990's. Concern at the high recidivism rate for sex offending has led to special attention being placed on preventing those convicted from reoffending. In California for example, some convicted paedophiles are chemically castrated. ${ }^{2}$ Other jurisdictions have placed greater emphasis

* This paper was submitted as part of the LLB (Hons) degree programme at Victoria University of Wellington, 1997.

1 JA Houston "Sex Offender Registration Acts: An Added Dimension to the War on Crime" (1994) 28 Ga L Rev 729, 743.

2 Section 645 California Penal Code (West Supp. 1997). 
on informing the community about sex offenders. In Louisiana, a judge has the right to order a convicted paedophile to wear special clothing, or post signs on his house, or place bumper stickers on his car, indicating his criminal past. ${ }^{3}$ Elsewhere in the United States, legislation ensures that the release of offenders regarded as "sexual predators" results in general media and community notification. ${ }^{4}$ In Britain, measures are less extreme. British police are entitled to release information only to specific sectors in the community such as schools, creches, and other community groups involved in the care of children. ${ }^{5}$

New Zealand now has its own version of community notification, although it is not codified as its overseas counterparts are. Instead, a private citizen, Deborah Coddington, has published a book entitled The 1996 Paedophile and Sex Offender Index. ${ }^{6}$ It contains the names of over 580 people (mostly men) who have been convicted of a range of sex offences in New Zealand. Yet this book, as with overseas public notification schemes, raises important questions involved in balancing the public's right to know about an individual with that individual's right to privacy.

The balancing exercise is reflected in the format of this article. Part II outlines the information contained in Coddington's book and the responses it has received. Part III discusses whether the information could be regarded as private at all; special emphasis is placed on the issues arising from a claim under the tort of privacy. Part IV examines the persuasiveness of the public interests involved in publication and whether they could be considered strong enough to outweigh privacy concerns. Finally, Part V describes some notification schemes overseas and how they attempt to protect the community while minimising infringements on privacy.

This article suggests that a balancing exercise between the interests of sex offenders and the interests of the community results in a need to take greater care before general dissemination of information of this nature. It is a topic which has received little coverage in the academic literature and as New Zealand contemplates a sex offender notification scheme similar to Britain's, it seems timely to examine the privacy concerns involved.

3 Above $\mathrm{n} 1$.

4 Washington Community Protection Act, ch. 3, 1990, Wash. Laws 12.

5 "Plans for Paedophile Warnings Welcomed" The Dominion, Wellington, New Zealand, 12 August $1997,5$.

6 Deborah Coddington The 1996 Paedophile and Sex Offender Index (Alister Taylor Publishers Pty Ltd, Auckland, 1996). 


\section{THE 1996 PAEDOPHILE AND SEX OFFENDER INDEX}

The New Zealand edition was published in June 1996 although it is presently unavailable for sale. This is because it is enmeshed in a $\$ 200,000$ defamation claim brought by a man named in the book. He is reported as having been convicted of raping a thirteen year old girl but the book does not mention that the conviction was later set aside on appeal. The man concerned is arguing that his inclusion in the book wrongfully labels him as a recidivist paedophile. ${ }^{7}$

The 1996 edition contains the names of 309 people, convicted of sex offences with children under 16 years of age (the age of consent), and a further 275, convicted of sex crimes against adults. All but a few of the offenders are men. There are three indices in the book. Sex offenders are firstly listed alphabetically with a brief description of their crimes and sentencing details. For some convicted offenders, information on other charges which were not proven in court is also provided. The second index lists offenders according to their place of residence, and the final index lists offenders according to occupation. The underlying assumptions of this type of indexing are that offenders will continue to use their real names, live in the same area and pursue the same sort of occupation upon release from their sentence. These appear to be especially dangerous assumptions to make given the propensity for many offenders to go "underground" when they feel their anonymity is threatened. The difficulties this causes is examined in Part III of the paper.

An Australian edition was published in February 1997. ${ }^{8}$ It includes 29 photographs of sex offenders, an additional feature which was also planned for New Zealand's 1997 update. Coddington hopes to release a British edition later in 1997. Paperback editions have been sold in retail bookstores in both Australia and New Zealand to disseminate them widely amongst the public. Coddington claims the book should be available for "every parent, every Board of Trustee, every police station, and every youth group".9

Reactions in New Zealand and Australia have been similar, with both editions selling well. In July 1996, before it was withdrawn, the book was fifth in New Zealand's bestsellers list. ${ }^{10}$ Earlier this year in Australia, 5000 copies were ordered within two days of Coddington's arrival in Sydney. ${ }^{11}$ The book is especially popular with parents. Yet

"A New Chapter on Child Abusers" The Dominion, Wellington, New Zealand, 19 August 1997, 7.

8 "Sales Boom for Paedophile List" Sydney Morning Herald, Sydney, Australia, 22 February 1997, 10.

9 Radio interview between Kim Hill and Deborah Coddington, Radio New Zealand, 13 May 1996.

10 "Best Sellers List" National Business Review, Wellington, New Zealand, 19 July 1996, 5.

11 Above $\mathrm{n}$. 
adverse reaction has also been strong, and Coddington received death threats after releasing New Zealand's edition. ${ }^{12}$ Civil libertarian groups and those involved in rehabilitating sex offenders have particularly voiced their disapproval. In Australia, the Parents and Citizens Federation, representing one million parents, are concerned about this book because of the climate of "fear and loathing" it could generate.

The Federation claims judicial reform would be a more effective way of dealing with offenders than a measure which could promote vigilantism. ${ }^{13}$

All information in Coddington's book has been accessed from media reports and official court reports from 1990 onwards. Therefore, only those who were not granted name suppression have been included. This raises important issues such as whether a privacy interest may be asserted over some matters of public record and whether public information may, over time, become private once more. Indeed, it is arguable that felons have forfeited their right to assert a privacy interest at all over conviction information. These issues are considered in Part II of this paper.

The object in publishing the book is outlined by Coddington in her introduction: ${ }^{14}$

If this book prevents merely one person from being a victim of a sex crime, then the stress and distaste involved in putting it together will have been worthwhile.

An informed public then is regarded as being a safer one. This theory also underpins public notification schemes overseas. Coddington has a special concern for protecting children. The book arose from research Coddington was conducting for another book, entitled Keeping Kids Safe. ${ }^{15}$

It does raise the issue however of whether notification in this way does create a safer community. There may well be individuals in the book whose inclusion does not promote this objective because they are unlikely to reoffend. Even if reoffending is possible there could be more effective ways of promoting a safer community. These issues are dealt with in Part IV of the paper.

\footnotetext{
12 Above $n 9$.

13 Above $\mathrm{n} 8$.

14 Above n 6, 12.

15 Above n 6, 9.
} 


\section{THE RIGHT TO PRIVACY}

\section{A Basic Definitions}

Privacy has been defined at its most fundamental level as "the right to be let alone". ${ }^{16}$ This suggests a zone surrounds every individual within which an individual should be protected from intrusion by others. ${ }^{17}$ Thus under this definition, all those named in Coddington's book have a right to at least some privacy. The dispute centres on the extent to which they should be "let alone".

Although many theories of privacy exist, Professor Gerety's conception is especially convincing in a technological society more intrusive than ever before. He understood a successful privacy claim as requiring three elements. ${ }^{18}$ The first element is autonomy the retention of control over one's destiny as an individual. The stigma attached to sex crimes means most offenders will lose some control over their destiny. When such information is widely distributed the loss of control is even more significant. The second element is identity - the ability to develop one's potential as an individual. Sex offender notification schemes overseas have been described as a "Scarlet Letter", because they continually hinder an individual's progress in any endeavour, especially one which is publicly visible. ${ }^{19}$ The third element is intimacy - the right to at least some secrecy from the public. Revelations of past criminal conduct are likely to subject offenders to public ridicule. At its extreme the threat of vigilante attacks means many offenders do not feel safe in their homes.

\section{B International Legislation}

Professor Gerety's conception of privacy underlies article 12 of the Universal Declaration of Human Rights 1948 and article 17 of the International Covenant on Civil and Political Rights 1966 (ICCPR). Article 17 states:

(1) No one shall be subjected to arbitrary or unlawful interference with his privacy, family, home, or correspondence, nor to unlawful attacks on his honour and reputation.

(2) Everyone has the right to the protection of the law against such interference or attacks.

The historical background to the ICCPR suggests article 17 prohibits only those impairments to a person's honour and reputation which are committed unlawfully and

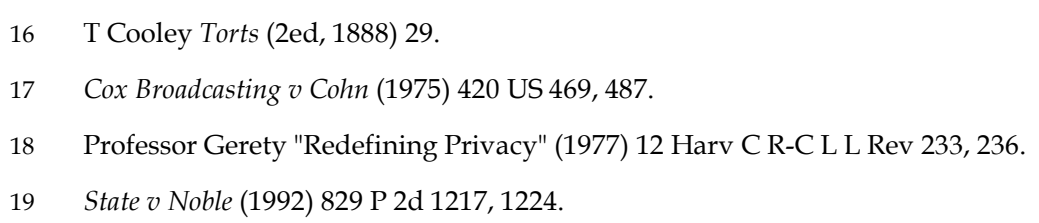


intentionally and are based on untrue allegations. ${ }^{20}$ In New Zealand honour and reputation are protected by defamation law. Defamation will generally be inapplicable to Coddington's book because she has included only felons whose allegations against them have been proven true in a court of law. It is worth noting however that a factual mistake or inaccuracy in Coddington's book may result in liability for defamation because truth can no longer be used as a defence. As mentioned above, New Zealand's 1996 edition is being withheld from bookstores because of a challenge on this ground. Indeed, considering Coddington is using the media as an information source, there is a distinct possibility of further inaccuracies and defamation claims. Misreporting in the media does occur and Coddington will be liable even when she has merely copied an inaccurate source. ${ }^{21}$

Privacy, family, home, and correspondence have greater protection because they are also protected from interferences deemed "arbitrary". "Arbitrary" includes elements of "injustice" and" unpredictibility" and applies even when the information is true. ${ }^{22}$

This paper is primarily concerned with the arbitrary interference of privacy. In determining what constitutes this, the ICCPR also recognises other rights which may justify interference with privacy. ${ }^{23}$ The right to freedom of expression is one example. This is an assumption that all speech, even speech which causes harm to some members of the public, is entitled to immunity from government restraint. ${ }^{24}$ This right assumes Coddington's book should not be restrained even if it brings shame or ostracises those who have been named. Balancing these rights pervades any discussion of privacy. It is a contentious issue worthy of analysis in itself.

\section{New Zealand's Recognition of Privacy}

In New Zealand, privacy interests from article 17 of the ICCPR have been recognised via section 21 of the New Zealand Bill of Rights Act 1990 (NZBORA): "Everyone has the right to be secure against unreasonable search and seizure, whether of the person, property, or correspondence, or otherwise". However courts have recognised privacy, not as a guaranteed right, but as the right of an individual to be protected in certain intrusive

20 Manfred Nowak United Nations Covenant on Civil and Political Rights: CCPR Commentary (NP Engel, Kehl, Germany, 1993) 306.

21 Truth (NZ) Ltd v Holloway [1961] NZLR 22, 26 as per Lord Denning.

$22 \quad$ Above n 20, 292.

23 Above n 20, 293.

24 Eric Barendt Freedom of Speech (Clarendon Press, Oxford, 1985) 1. 
circumstances, particularly when a government agency is involved. ${ }^{25}$ Therefore the NZBORA is inapplicable to Coddington's book. Coddington is a private citizen who is not intruding on anyone's physical space but is instead releasing information of a sensitive and embarrassing nature.

Despite this, New Zealand has indicated a willingness to recognise a right of solitude and this resulted in the passing of the Privacy Act 1993 (the Act). Although the Act is not a complete code of privacy, complaints can be made to the Privacy Commissioner who provides opinions on whether a privacy intrusion is justified. The Act covers any information which a public or private agency may hold or disclose about an identifiable individual.

However there are two reasons why the Privacy Act will probably not protect those named in Coddington's book. The first reason is that a specific exception is made in section 2(1) to any news medium. This is an organisation whose business consists of a "news activity". "News activity" is defined as including, under section 2(1)(a) the gathering or preparing of news, and under section $2(1)(b)$ the dissemination of this news to the public. Because Coddington is not in the business of gathering or preparing news her book could probably not be regarded as a news medium as such. However it is unlikely Coddington will be liable either. She has merely copied information generally available from media sources. Secondly, while Information Privacy Principles ten and eleven of the Act place limits on the disclosure of personal information, subsections (a) and (b) respectively hold these limits to be inapplicable if the organisation believes, on reasonable grounds, that the source of the information is a "publicly available publication". In section 2(1) a "publicly available publication" means a magazine, book, newspaper, or other publication that is or will be generally available to members of the public. This clearly includes Coddington's sources of information. Accordingly, Coddington will not be liable under the Privacy Act. Because the NZBORA is also inapplicable, the only possible avenue for remedy for those named in the book will be through tort. Thus, the remainder of this paper centres discussion on possible tortious liability.

\section{$D$ The Tort of Privacy}

Coddington's named offenders may have a common law claim for invasion of privacy under the heading of the "public disclosure of private facts". This tort was recently introduced into New Zealand by Tucker $v$ News Media Ownership. ${ }^{26}$ Justice Thorp in Hobson $v$ Harding concluded the tort of privacy continues in New Zealand despite the

$25 \quad R v$ Jefferies [1994] 1 NZLR 290, 302 (per Richardson J).

26 [1986] 2 NZLR 716. 
enactment of the Privacy Act in 1993. ${ }^{27}$ Prosser and Keeton identified three basic elements to this claim and this approach was affirmed in New Zealand by Bradley $v$ Wingnut Films Ltd. $^{28}$

Each element must be satisfied for there to be a breach of this type of privacy. They are: ${ }^{29}$

The matter made public must be one which would be highly offensive and objectionable to a reasonable person of ordinary sensibilities.

There must be public disclosure.

The facts must be private facts.

The Second Restatement of Torts suggested an element of "a lack of legitimate public interest in the information" must also be satisfied. ${ }^{30}$ In New Zealand it is unclear whether the lack of public interest will be treated as an element to be proven by the plaintiff or a defence with the onus of proof on the defendant. Certainly it is treated as a specific defence by the Broadcasting Standards Authority, and this approach was upheld by the High Court in TV3 Network Services Ltd. v Broadcasting Standards Authority. ${ }^{31}$ Other authority is less clear. Whatever its status the public interest is certainly a factor to be balanced with the individual privacy rights outlined by the three elements in the Prosser and Keeton test.

The publication of Coddington's book clearly satisfies the first two elements. Reasonable people would be highly offended by this disclosure because it is information of an embarrassing and objectionable nature. The book is on sale at retail stores around New Zealand. The disclosure has been made public and is available for purchase by anyone. It is less clear whether the third element of the tort, "facts must be private facts", will be satisfied. This is because several factors must be considered.

\section{Privacy expectation of released offenders}

Many think that those who are convicted of a crime have a lower expectation of privacy regarding publication of crime related information. This is simply because

27 (1995) 1 HRNZ 342, 354.

28 [1993] 1 NZLR 415.

29 WP Keeton, DB Dobbs, RE Keeton, DG Owen Prosser and Keeton on the Law of Torts (5ed, West Publishing Co, St. Paul, Minnesota, 1985) 856-857.

30 Restatement of the Law of Torts (Second) (American Law Institute Publishers, St. Paul, Minnesota, 1965), Comment d, s652D.

31 [1995] 2 NZLR 720. 
criminals should be expected to abdicate some of their civil rights to live a free and normal life just as their victim did at the time the crime was committed. Arguably however, those who have completed their sentence should be treated differently because they have already served their punishment. Publication in the way carried out by Coddington was not anticipated by the courts when they sentenced the offenders. Certainly as time elapses, one would expect the privacy expectation of these offenders to increase as the "stigma" of their offence lessens.

A probable exception to this occurs if released offenders are regarded as "public figures". 32 A public figure is a person whose fame (or infamy), or mode of living, gives the public a legitimate interest in her affairs and character, even when the figure concerned has not consented to such publicity. ${ }^{33}$ Legitimate interest continues in a public figure even when that person has not been exposed to publicity for some time. For example, in Sidis v F.R. Publishing Corporation, ${ }^{34}$ the court held that a magazine which detailed the personal habits of a former childhood prodigy had a legitimate interest in that person's departure from the limelight.

Arguably there are only a few sex offenders who achieved similar "celebrity" status before they were imprisoned. These include Joseph Thompson, dubbed "The South Auckland Rapist" by the media, Stewart Murray Wilson, dubbed "The Beast of Blenheim" and Peter Ellis, the Christchurch Civic Creche worker. The publicity surrounding their crimes suggests they have become public figures and there will be no liability for the additional publication of matters within the scope of the public interest they have aroused. Accordingly, it will always be difficult for them to "depart from the limelight" and assert a privacy right even when their formal punishment has been served.

Another factor affecting privacy expectation is the nature of information released. The recent case of Doe $v$ Poritz ${ }^{35}$ is important because it upholds the constitutionality of the Sexual Offender Registration Act in New Jersey, a statute dubbed "Megan's Law" which allows public notification for some sex offenders. Doe $v$ Poritz held that there was no privacy expectation in individual pieces of information such as name, conviction, appearance, place of employment or school attended because they were not regarded as the sort of intimate information which the law of privacy should protect. ${ }^{36}$ Coddington's

\footnotetext{
32 Above n 29, 860.

33 Cason v Baskin (1947) 159 Fla. 31.

$34 \quad$ (1940) 113 F 2d 806.

35 (1995) 662 A 2d 367.

36 Above n 35, 408 .
} 
book contains the very sort of information which was not regarded as intimate by the court in Doe v Poritz.

However, Professor Gerety's conception of intimate information could include sex conviction details. Gerety thought a breach of privacy included "that intentional psychological intrusion that takes place when publicity is given to such intimate and secluded details of our lives as to embarrass and humiliate us". ${ }^{37} \mathrm{He}$ was concerned that such public disclosure could diminish an individual's right to share intimate information only with those the individual chooses. ${ }^{38}$ Sex convictions, even for less serious offences, carry a stigma which other convictions do not. This can be seen by the reactions of others to people convicted of sex crimes. Certainly the risk of vigilantism is more apparent than for other crimes. In order for released sex offenders to regain some measure of autonomy or control over their lives it is often necessary to seclude such information. Consequently, unless the sex offender in question attracted the sort of publicity surrounding his offence which could properly label him as a public figure, in the author's opinion a legitimate privacy expectation is formed.

\section{Matters of public record}

Even if released offenders generally have a privacy expectation this could be displaced because criminal convictions are a matter of public record. American authority suggests there will be no liability for giving publicity to facts about someone's life which are matters of public record. ${ }^{39}$ In Cox Broadcasting $v$ Cohn $n^{40}$ the Supreme Court refused to recognise a privacy interest in the identity of a deceased rape victim because the identity was available in official court records open to the public.

The Supreme Court decided that the First Amendment to the United States Constitution protected media reporting of these records. Where matters of public record were concerned, the right to freedom of expression was accorded greater emphasis than a right to privacy. Judge White was reluctant to make an exception if the information was offensive because this would invite timidity and self censorship within the media. ${ }^{41}$ This underpins the theory of a public trial - the notion that any member of the public (including the media) may watch and report on a sentence being delivered. Coddington's

\footnotetext{
$37 \quad$ Above n 18, 263.

38 Above $\mathrm{n}$ 18, 268.

39 Above $\mathrm{n} 30$.

$40 \quad$ (1975) 420 US 469, 487.

41 Above n 40, 496.
} 
book appears to be protected by this theory because it has merely repeated reports taken in open courtrooms around the country.

However, different matters of public record have different degrees of public availability. In US Department of Justice $v$ Reporters Committee for Freedom of the Press ${ }^{42}$ information was gathered in a police "rap sheet" which contained descriptive details about an individual such as date of birth and physical characteristics, as well as his history of arrests, charges and convictions. This information was compiled from various law enforcement agencies around the United States. Even though the rap sheet was a matter of public record this did not negate an individual's privacy interest in nondisclosure of the report.

The Supreme Court thought "the compilation of otherwise hard-to-obtain information alters the privacy interests implicated". ${ }^{43}$ Coddington has compiled information from sources around New Zealand and placed them in a single publication in a similar way to the police in US Department of Justice. The Supreme Court judgment suggests that if it is "hard to obtain" or access this conviction information then those named in Coddington's book will have strong privacy interests.

An important reason for upholding the constitutionality of "Megan's Law" in Doe v Poritz was the fact that conviction information was readily available to researchers anyway. It was noted that in most New Jersey counties it is possible to go to the courthouse and request any individual's criminal record within that county, providing only the individual's name and address. ${ }^{44}$ "Megan's Law" simply makes identification more convenient. In New Zealand access to another person's criminal record is more difficult. Certified copies of court records may be accessed from each individual court but researchers must know where and when the conviction took place. Even then registrars of the courts will refuse access unless convinced a researcher has a "genuine and proper reason" to have it. Although there is no set criteria for determining this, a researcher's desire to publish the information will certainly result in a denial of access. ${ }^{45}$ Another avenue of access is through application to the National Office of the Department of Courts but this requires the written consent of the individual being researched. ${ }^{46}$ Such restrictions on public availability suggests that New Zealand recognises a stronger

\footnotetext{
42 (1989) 489 US 749.

43 Above $n$ 42, 764-765.

44 Above n 35, 407.

45 Personal interview with Wellington District Court Registrar, 28 August 1997.

46 Personal interview with Privacy Officer, Dr Andrew Jack, Police Validation Office, 20 August 1997.
} 
privacy right to conviction information than New Jersey. Indeed, New Zealand has a tradition of protecting the identity of those with criminal records. The Wanganui Computer Centre Act 1976 for instance, was passed to place controls on the storage, retrieval and use of law enforcement information on the Wanganui computer system. Under section 14 individuals only had the right to access and correct information about themselves. Although the Privacy Act 1993 repealed this Act the same restrictions on access apply.

Coddington's book could be viewed with greater suspicion by New Zealand courts than American courts because of the limited public availability of criminal records. With publication, Coddington is substituting her own view of "genuine and proper reason" for those of the registrars of the courts and she has certainly not sought the consent of those concerned before publishing their names. It is questionable whether this is a decision she should be entitled to make especially considering New Zealand's traditional concern in preserving the privacy rights of convicted criminals.

\section{Republication of information}

Coddington's book contains information already reported on by the media and hence already in the public domain. Unlike many matters recorded on a public register this particular information has been compiled by the media and is freely available to members of the public. However, information once public and disseminated by the media, may become private over time. In Melvin $v$ Reid $^{47}$ a prostitute was tried and acquitted for murder and afterwards married into respectability. Her right to privacy was recognised when she discovered a film, produced eight years after her acquittal, planned to portray her early life. Similarly, in Briscoe v Readers Digest Association White J stated: ${ }^{48}$

Human forgetfulness over time puts today's "hot news" in tomorrow's "dusty archives". It

would be a crass legal fiction to assert that a matter once public never becomes private again.

TV3 Network Services Ltd $v$ Broadcasting Standards Authority ${ }^{49}$ suggests that the Broadcasting Standards Authority has affirmed this approach. In this case, a television network screened a documentary about a man who had committed incest with his five daughters. The plaintiff, who was the man's wife, had earlier testified in open court that she herself had been an incest victim.

The documentary included an interview with the plaintiff, and although her face was concealed it was revealed by voice-over that she had been a victim. The Broadcasting

$47 \quad$ (1931) 297 P 91.

$48 \quad$ (1971) 483 P 2d 34, 41.

49 [1995] 2 NZLR 720. 
Standards Authority held that this was enough to identify the plaintiff to her friends and acquaintances and therefore the programme had failed to maintain the appropriate privacy standards in section 4(1) of the Broadcasting Act 1989.

In its advisory opinion the Authority held that the protection of privacy also protects against the public disclosure of some kinds of public facts. The Authority specifically mentioned criminal behaviour as an example of a public fact which may become private again through the passage of time. ${ }^{50}$ Interestingly, although the Authority's opinion was affirmed by the High Court, Eichelbaum CJ considered it difficult to equate the case with Melvin $v$ Reid because in TV3 Network Services Ltd not even a year had elapsed before the information was made public. ${ }^{51}$

Coddington's book is more easily equated with Melvin $v$ Reid since convictions date back to 1990 and in most cases there has been a lapse of years before conviction information was publicised again. Having established this, the issue then arises as to whether, in the language of Briscoe, sex offending is news which may, over time, be placed in the "dusty archives" and have a privacy interest asserted over it.

Tucker $v$ News Media Ownership ${ }^{52}$ is a New Zealand case suggesting there is a privacy interest in a sex offence conviction. In this case Mr Tucker's fundraising campaign for a lifesaving heart transplant was endangered when a newspaper threatened to publish details of his previous convictions. The most recent conviction was for indecent assault, only four years before publication. Mr Tucker sought an injunction to restrict further broadcasting of these details. Justice McGechan thought the right to privacy was a valid cause of action here. He was sympathetic to Mr Tucker's plight and hoped the rest of the community would be also. ${ }^{53}$

Justice McGechan held a privacy interest may be lost where a person presented himself to the public eye for evaluation but that was not the case here. Mr Tucker was a "reluctant debutante" to the publicity because of the necessity of raising fundraising for his condition. ${ }^{54}$ Despite recognising a privacy interest, McGechan J refused to award an injunction, considering this to be "futile" because of the widespread publicity Mr Tucker was receiving through other media organisations. ${ }^{55}$

\footnotetext{
50 Above $n$ 49, 726.

51 Above n 49, 732.

52 [1986] 2 NZLR 716

53 Above n 52, 736.

54 Above n 52, 735.

55 Above n 52, 736 .
} 
This case is particularly useful for Coddington's offenders as it discusses the three aspects of "facts must be private facts" addressed by this article. Mr Tucker was regarded as having a legitimate privacy expectation in his sex conviction information. The intimacy of the information is graphically illustrated here because the revelation threatened to halt a campaign to raise sufficient funds for an operation to save Mr Tucker's life. The threat of this type of reaction suggests sex offenders generally have some interest in keeping the information secret. Also, the fact the sex conviction was a matter of public record, or the fact it had already been published widely, did not preclude a privacy interest. Interestingly, the length of time between conviction and publication is very comparable to those in Coddington's book. Mr Tucker was accorded a privacy interest even though his conviction was only four years previously and some of Coddington's offenders have convictions dating back to 1990, six years before publication. According to Tucker strong privacy interests are apparent here. It must be noted however that McGechan J was particularly concerned about the life threatening consequences surrounding disclosure of Mr Tucker's past. Future courts could be less sympathetic to other sex offenders if the consequences are likely to be less severe.

Although an injunction was refused in Tucker because it was considered "futile" in the circumstances, pursuing such a remedy against Coddington's book may be more successful. In TV3 Network Services Ltd v Broadcasting Standards Authority, Eichelbaum CJ, while not directly addressing the injunction issue, recognised that the particular defendant had breached the Broadcasting Act even though there had been recent publicity surrounding the wife's victimisation. The situation was distinguished from Tucker because in this case previous publicity had been "slender" consisting mainly of the publication of an old photograph. ${ }^{56}$ Eichelbaum CJ saw no reason why other members of the media should be allowed to exacerbate the damage which had already occurred. A similar approach was taken by Holland J in Morgan $v$ TVNZ. ${ }^{57}$ In this case an injunction was awarded against publication of a television documentary about a seven year old at the centre of a bitterly contested custody dispute. The injunction was awarded even though there had been previous publicity of the facts of the case. Justice Holland was concerned that further publication would simply damage the child further. Coddington's book may also be distinguished from Tucker because in many cases conviction details received little media coverage prior to Coddington's publication. Generally there was not the same sort of nationwide dissemination as with Coddington's book.

\footnotetext{
56 Above n 49, 726.

57 Unreported, 1 May 1990, High Court, Christchurch Registry, CP 67/90.
} 
Therefore, unless offenders gained such publicity at the time of their conviction so that they could be properly labelled as public figures, the previous attention placed on them could be regarded as "too slender" to dismiss injunction claims.

\section{A MATTER OF LEGITIMATE PUBLIC INTEREST?}

Although the previous section recognised privacy interests in the information in Coddington's book according to the third element of the Prosser and Keeton test, the public may still have a legitimate interest in this information. If this is considered to outweigh the privacy interests involved then recovery under this tort will be denied.

Coddington claims her book was prompted, not by a witch hunt, but by a genuine concern to inform the community and thus make it safer. ${ }^{58}$ Although an author's motivation does not determine the issue, it certainly suggests an examination of the public interests in publication is required before claims of unjust privacy infringement can be made.

Although courts have recognised disclosure of many different types of information as being in the "public interest", information concerning actual criminal conduct has been considered especially important. This began with comments by Wood VC in Gartside v Outram. ${ }^{59}$ Despite being made in the context of a breach of confidence action his comments are also applicable to a claim in privacy. The essence of both actions is the prevention, in certain circumstances, of disclosing information. Indeed the breach of confidence avenue has become popular overseas for advancing more general privacy claims, and so observations in this area are applicable to the present case. ${ }^{60}$ ViceChancellor Wood stated: "there is no confidence as to the disclosure of iniquity".61 Iniquity includes at least crimes and frauds and perhaps other civil wrongs also. ${ }^{62}$

Coddington's book is concerned with proven sexual misconduct, a type of iniquity society regards as particularly abhorrent. In fact, even information which merely raises a suspicion or risk of criminal wrongdoing, has been protected by courts as being in the public interest. This is because disclosure is seen as necessary for detecting or protecting against crime. ${ }^{63}$

"Letter Misinformed" (Letter to the editor from Deborah Coddington) The National Business Review, Wellington, New Zealand, 24 April 1997, 3.

59 (1857) 26 LJ Ch (NS) 113.

60 Younger Committee on Privacy (1972) Cmnd 5012.

61 Above n 59, 114.

62 Initial Services $v$ Putterill [1967] 3 WLR 1032, [1967] 3 All ER 145 as per Lord Denning.

63 Malone v Metropolitan Police Commissioner [1979] Ch 344, 377, 2 All ER 620, 653. 


\section{A Public Knowledge as Public Safety}

Courts agree with Coddington that an informed public is a safer one. An example of this attitude is the opinion in Hellewell $v$ Chief Constable of Derbyshire, ${ }^{64}$ a recent case which discusses the right of the public to be informed of a threat of criminal activity. In this case, after being convicted of shoplifting offences, the plaintiff discovered his name and photograph had been distributed to local shopkeepers. He claimed the police had breached his confidence. The court held that a pre-existing obligation of confidence towards the plaintiff did arise because the plaintiff was given no choice by the police regarding the taking of the photograph. However the court held there was a good public interest defence here because the photograph was used for the prevention and detection of crime. ${ }^{65}$ The court was satisfied the police had acted entirely in good faith for the prevention of crime and had distributed information only to those who had a reasonable need to make use of it. ${ }^{66}$

Following the reasoning in Hellewell, Coddington has strong public interest claims in publishing her book. She too is acting in good faith by publishing a book to restrict future reoffending. Her claim is strengthened by the fact that, unlike the police in Hellewell, she has no pre-existing obligation of confidence to the offenders in her book. This is a situation where the information has already been released by someone else into the public domain. Since photographs in Hellewell were considered necessary to identify potential offenders, even the photographs in Coddington's Australian edition appear to be protected by this decision, since they are included for the same purpose.

A similar case is Paul $v$ Davis, ${ }^{67}$ a case often used to uphold the legality of public notification statutes throughout the United States. ${ }^{68}$ The facts were identical to Hellewell except here the plaintiff was found not guilty of the shoplifting charges. As in Hellewell, the majority dismissed the plaintiff's claims. Their opinion was not based on breach of confidence, but rather on a lack of constitutional restrictions in publishing an official act such as an arrest. The Supreme Court was only prepared to accept a privacy right for "fundamental conduct" such as: marriage, procreation, contraception, family relationships, child rearing and education. The implication here is of an inadequate public interest in knowing about these activities. Gerety would probably consider them

\footnotetext{
64 [1995] 1 WLR 804.

65 Above n 64, 810.

66 Above n 64, 809, 810.

67 (1976) 424 US 693.

68 Catherine Trinkle "Federal Standards for Sex Offender Regulation: Public Disclosure Confronts the Right to Privacy" (1995) 37 Wm and Mary L Rev 299, 315.
} 
as being examples of intimate information which should be protected to prevent their value being diminished. However, since Griswold $v$ Conneticut ${ }^{69}$ refused to recognise legislative bans on the use of contraceptives, American courts, in protecting forms of "fundamental conduct", have focussed on preventing the interference by State powers with the individual right to exercise such conduct. It may be that after Tucker, New Zealand is willing to expand the notion of "fundamental conduct" to include sexual criminal history and protect this information not only from interference by the State but from interference by others also.

Despite this possibility, following Paul v Davis, Coddington has strong public interest claims in publishing her book. She too, is merely publishing a record of an official act to restrict future reoffending. No such "fundamental conduct" alluded to by the Supreme Court has been included in the book. Paul $v$ Davis also suggests the descriptions Coddington has already provided on the unproven charges against each offender, will be protected. Brennan J dissented strongly in Paul $v$ Davis. He thought the law enforcement reasons for broadcasting an arrest which did not culminate in a conviction were outweighed by privacy concerns. In the balancing exercise which ensues, the State should recognise that many employers would treat an arrest as evidence of criminal culpability and unfairly deny employment on that basis. ${ }^{70}$ Although all the individuals in Coddington's book were criminally culpable because of their conviction in a court of law, Brennan J's dissent suggests no public interest is served in knowing about the charges against each offender which remained unproven in court. In some instances these charges have been outlined in the book.

The major difference between the facts in Hellewell and Paul $v$ Davis and the facts in the present case concern the scale of dissemination of information. In the shoplifting cases above information was circulated only amongst local shopkeepers who clearly had an interest in reducing theft from their stores. Coddington's book however is sold in paperback in retail bookstores around the country. It is readily available for purchase by anyone, many of whom have little contact with children and have no legitimate interest in the information but are simply curious about its contents. This is a distinction Brennan $\mathrm{J}$ was alluding to in Paul $v$ Davis. Just because information is interesting to members of the public does not necessarily make it legitimately within their interest to receive. The media in particular tend to benefit from information with high curiosity appeal.

69 (1965) 381 US 479.

70 Above n 67, 735 
Satisfying a public interest does not necessarily require general dissemination. ${ }^{71}$ The incest case is a particularly interesting one to consider. There appears little safety interest in releasing incest information to the general public since those who commit incest are unlikely to be dangerous outside the family setting. ${ }^{72}$ Unless dealing with "sexual predators" even sex offender statutes overseas are careful to release information only to those specific sectors in the community such as schools, creches, and scout groups, which have a clear interest in receiving it. $^{73}$

Arguably, all parents do have some interest in this information. Since parents come from such a broad cross-section of society, general dissemination appears an effective way of delivering information to them. What is unclear however is whether general dissemination would improve the safety of children to the same extent that information about petty thieves enhanced shop security in the shoplifting cases above. Once offenders become aware of such dissemination the ease with which they may change identity and become anonymous may actually detract from public safety and do little more than create the climate of fear and loathing which concerns The Parents and Citizens Federation in Australia. Such actions from offenders are less likely when information is disseminated on a smaller scale.

Therefore, although notification may promote safety interests in the community, it will probably only do so when dissemination occurs in specific sectors. Coddington's book does not do this directly and because of this, claims of a legitimate public interest in her book appear weaker. General dissemination in this way makes it more likely that the book could be regarded as satisfying a general curiosity interest rather than a legitimate law enforcement one.

\section{B Public Knowledge as Encouragement for Victims}

Although specific dissemination is more effective in providing a safer community, general dissemination may provide benefits too. It is surely in the public interest that other victims of sex crimes are encouraged to report offences. This may be done when community notification places the "spotlight" on sex offenders in general and is especially

71 Stephen Todd The Law of Torts in New Zealand (2ed, Brookers, Wellington, 1997) 811.

72 Caroline Louise Lewis "The Jacob Wetterling Crimes Against Children and Sexually Violent Offender Registration Act: An Unconstitutional Deprivation of the Right to Privacy and Substantive Due Process" (1996) 31 Harv C R-C L L Rev 89, 92. 
applicable to sex offences where the reporting rate has traditionally been very low. One researcher suggests as few as 15 per cent of sex crimes actually lead to incaceration. ${ }^{74}$

However other measures have already been enacted to encourage victims. For instance men can now be convicted on the uncorroborated word of women and children. ${ }^{75}$ This is important in a crime where many offenders "leave no smoking guns". ${ }^{76}$ That is, there is often little physical, medical or forensic evidence to implicate guilty parties. Female rape victims now also have greater assistance from the law. They can no longer be interrogated in court about their sexual history. ${ }^{77}$

Therefore general dissemination may provide encouragement for victims to report sex crimes because it promotes a climate where these crimes are regarded as unacceptable and where victims feel more supported than they have in the past. However, it is the changes to the evidence legislation which will probably be the determining factor in convincing victims to testify in court.

\section{Public Knowledge as Reducing Reoffending}

Even if only specific community sectors receive Coddington's information, public interest arguments will be weaker where offenders show no inclination to reoffend and offer little threat to public safety. The likelihood of reoffence is measured by the recidivism rate and was an aspect of crime which was not discussed in Hellewell and Paul $v$ Davis. In these cases, the police were genuinely concerned that the plaintiffs would shoplift in the future. Petty crimes in general, tend to attract repeat offending. For instance, in a New Zealand study, various forms of theft and other non-violent crimes had a reconviction rate of 64 per cent. ${ }^{78}$ Coddington's authorship was itself based on an assumption that many convicted sex offenders will offend again. If this is correct, there are strong public interest justifications for at least publishing the information in some form.

74 GG Abel and JL Rouleau "The Nature and Extent of Sexual Assault" in WL Marshall, DR Lewis, HE Barbaree (eds) Handbook of Sexual Assault: Issues, Theories and Treatment of the Offender (Plenum Press, New York and London, 1990) 109.

75 Section 3 Evidence Amendment Act (No2) 1985.

76 Above n 68, 323.

77 Section 2 Evidence Amendment Act (No2) 1985.

78 Bruce Asher Reoffending and Parole: A Study of Recidivism Before and After The Criminal Justice Act 1985 (Department of Justice Policy and Research Division, July 1988) 43. 
Certainly, there is a perception that sex offending has an unusually high recidivism rate. ${ }^{79}$ This is an unfortunate oversimplification because recidivist rates vary according to the type of sex offence committed. For example, for untreated convicted sex offenders, studies suggest: over $40 \%$ of exhibitionists and voyeurs will reoffend, ${ }^{80} 15-38$ per cent of paedophiles will reoffend, ${ }^{81} 20$ per cent of rapists will reoffend, ${ }^{82}$ and less than 10 per cent of those who committed incest will reoffend. ${ }^{83}$

If recidivism rates are crucial in determining a public interest then there appears to be more concern in knowing about exhibitionists and voyeurs for instance, than those who committed incest. Coddington's primary focus in publication is on paedophilia. ${ }^{84}$ Although the statistics are inconclusive, if paedophiles do reoffend at the rate of only $15 \%$, publication would have to be justified on a ground other than the threat of reoffending. Studies suggest the threat of recidivism also has a strong correlation with other factors such as the offender's psychological, emotional, and economic state at the time of the offence, whether the offender had been a victim of abuse as a child, and whether the offender (and/or the victim) was intoxicated at the time of the offence. ${ }^{85}$ Coddington may discount these factors as providing no excuse for sexual misconduct but these factors are also important when determining the likelihood of further reoffending. The impact of such factors also suggests a case-by-case analysis provides better justice than simply assuming all are likely to reoffend and grouping them together in a book available for dissemination. To the book's credit, the descriptions of the nature of each offence may allow the public to delineate the truly dangerous offenders from the less dangerous ones. Arguably however there is no public interest at all in knowing about the offender in the second scenario outlined at the beginning of this article.

By itself, perceptions of recidivism cannot provide the basis for establishing a public interest in sex offender information. There are other violent crimes also with high

79 Keith Soothill and Sylvia Walby Sex Crime in the News (Routledge, London and New York, 1991) 103.

80 D Robinson Research on Sex Offenders: What Do We Know? (Corrections Research Forum 1(1), 1989) 12-20.

81 K McLaren Reducing Reoffending: What Works Now (Department of Justice Penal Division, Wellington, May 1992) 10.

82 D Marshall, R Jones, T Ward, P Johnston, HE Barbaree "An Optimistic Evaluation of Treatment Outcome with Sex Offenders" (1991) Journal of Interpersonal Violence 22.

83 Above $\mathrm{n} 80$.

84 Radio interview between Kim Hill and Deborah Coddington, Radio New Zealand, 13 May 1996.

85 Australian Law Reform Commission Evidence Interim Report-No 26 (Australian Government Publishing Service, Canberra, 1985) 3. 
recidivism rates, and no public notification schemes for these crimes have been seriously considered. In England, one politician has argued for indexing well known drug suppliers, but as yet no further action has been taken. ${ }^{86}$ Perhaps this is because there are more effective ways of making people safe. The rehabilitation of criminals is one such method.

\section{Public Knowledge in Hindering Rehabilitation}

Rehabilitating sex offenders has proven particularly difficult and early studies suggested there was no evidence that treatment could decrease sex offence recidivism. ${ }^{87}$ If rehabilitation is indeed unsuccessful, there will be strong public interests in promoting alternative methods which make the community safer.

However sex offender treatment programmes are now more comprehensive than before. Their techniques address offender cognitive characteristics and also include a relapse prevention component, teaching offenders, particularly paedophiles, how to cope with high risk reoffending situations. This component is based on recognising "warning signals" and although different for each paedophile, typically includes: loitering around schools, resumption in using child pornography, and excessive consumption of alcohol. ${ }^{88}$ Treatment by this sort of programme, reveals recidivist rates of: 6-9 per cent for exhibitionists and voyeurs, 13.6 per cent for homosexual paedophiles, $5.3 \%$ for heterosexual paedophiles, and 20 per cent for rapists. ${ }^{89}$ The Kia Marama unit in Christchurch is the major facility in New Zealand for treating sex offenders, and it uses these proven techniques.

Of the 434 men released since the programme's inception in 1989, approximately $8 \%$ have been reconvicted for a sex offence. ${ }^{90}$

Especially notable is the lack of success in treating rapists, those who have non consensual sexual intercourse with adults. ${ }^{91}$ Techniques used to treat other sex offenders will be unsuccessful with rapists because they have very different desires. While child

\footnotetext{
$86 \quad$ Above n 79, 96.

87 L Furby, MR Weinrott, L Blackshaw "Sex Offenders Recidivism: A Review" (1989) 105 Psychological Bulletin 3-30 and ME Rice, VL Quinsey, GT Harris (1991) 59 Journal of Consulting and Child Psychology 381-386. Wellington, 22 August 1997.

89 Above n 82.

90 Personal interview with Sarah Babbington, Kia Marama, Christchurch, 25 August 1997.

91 Above n 81, 57
} 
molesters, for instance, are motivated by sexual stimulation, rapists are generally motivated by power, aggression, and desires to humiliate and degrade. ${ }^{92}$ Presently, no effective rehabilitation programme for rapists exists. Therefore, there are stronger public interest claims in alternative methods which protect against rapists rather than other sex offenders. If notification is deemed one such effective alternative, Coddington has a more powerful claim to publicise rape convictions than other sex offences.

If sex offender rehabilitation is in the public interest then measures which purport to assist the community but actually detract from rehabilitation could be deemed "needless". ${ }^{93}$ Sex offender statutes overseas have been criticised on this ground. The disclosure of sex offenders' sensitive, personal information could not only hinder the rehabilitation process but may even make offenders more dangerous. This occurs when sex offenders feel compelled to go "underground". When sex offenders seek anonymity in this way, it is difficult for law enforcement agencies to exercise surveillance and offenders also lose contact with the treatment designed to control their sexual tendencies. Increased pressure on a fragile mental state in the process of being stabilised through therapy may actually increase the risk of reoffending. ${ }^{94}$

There are however conflicting opinions on this. Dr Barry Kirkwood, Senior Psychology Lecturer at Auckland University, believes many sex offenders will feel less stigmatised by Coddington's book because they are simply one of a list of offenders. ${ }^{95} \mathrm{Dr}$ Kirkwood claims publication forces individuals to acknowledge their problems and actually aids in the rehabilitation process. It is difficult to understand though what Coddington's book would achieve in this respect that the offender's previous prison sentence would not. Indeed, it appears to be in the public's safety interest that those in the process of rehabilitation should be "let alone" by the wider community. Some offenders however do refuse to attend rehabilitation programmes upon their release from prison. Arguably, at the very least, a safer community will be promoted by some notification about these individuals. In fact, longer prison sentences may be even more effective in providing safety (at least for the duration of the sentence), but this is an issue outside the scope of this article.

92 Above $\mathrm{n} 81,49$.

93 JA Houston "Sex Offender Registration Acts: An Added Dimension to the War on Crime" (1994) 28 G L Rev 743, 765.

94 Helen Edwards (National Association for the Care and Resettlement of Offenders) in "Paedophiles and Privacy" The Guardian, London, 2 July 1997, 20.

95 Radio interview with Dr Barry Kirkwood, Radio New Zealand Morning Report, 13 May 1996. 


\section{E Public Knowledge Hindering Basic Civil Rights}

The public interest is affected when notification impinges on the rehabilitation process. The public interest is also affected if notification impinges on an offender's right to a fair trial. The right to a fair trial has been defined as a "duty lying on everyone who decides anything to act in good faith and fairly listen to both sides". ${ }^{96}$ In New Zealand this right is protected by section 27(1) of the NZBORA and is regarded as important because it facilitates decisions which are informed, accurate, and instil a sense of fairness. It is in the public interest that this right is protected because impartiality in decision making maintains public confidence in the administration of justice. ${ }^{97}$ If, in the future, an individual in Coddington's book is charged with a crime once more, and Coddington's publication creates a reasonable suspicion or likelihood of bias from the jury, then the principle of a fair trial is breached. ${ }^{98}$

This is possible because a perusal of the book by a jury member may introduce facts and observations about an offender's past which will not be argued in the courtroom.

\section{$V$ LEGISLATIVE NOTIFICATION SCHEMES}

This article has suggested that general dissemination of information about sex offenders in the way carried out by Coddington's book is probably ineffective. Not only are there serious privacy concerns regarding this method but there are also serious concerns about whther it actually aids the public by reducing future sex reoffending. This is magnified by the fact that only one third of convicted offenders have been named by the book. The rest were granted name suppression and were not included. Certainly if notification was to occur a more comprehensive scheme is desirable. Indeed it appears New Zealand is contemplating a legislative scheme in an attempt to protect the community from repeat sex offenders. ${ }^{99}$ It is timely therefore to examine the types of legislative schemes overseas and how they deal with the privacy and rehabilitation concerns this article has raised.

On September 13, 1994 the Jacob Wetterling Crimes Against Children and Sexually Violent Offender Registration Act was passed into federal law in the United States as part of the Violent Crime Control and Law Enforcement Act 1994. This legislation encourages

\footnotetext{
96 Board of Education v Rice [1911] AC 179, 182.

97 Philip A Joseph Constitutional and Administrative Law in New Zealand (Law Book Company, Sydney, 1993) 717.

98 Above n 97, 740.

99 "Elder Seeks Report on Paedophile Warnings" The Dominion, Wellington, New Zealand, 13 August 1997, 1.
} 
states to adopt their own laws requiring released sex offenders to register with law enforcement agencies and allows these agencies to disseminate information about sex offenders including their name, address, and a photograph. Under all United States sex offender statutes, offenders are required to register with their local law enforcement agency upon release from their sentence. The registration requirement is essential for authorities to determine where offenders are residing and would of course have to be incorporated into any New Zealand legislative equivalent.

Under the Violent Crime Control and Law Enforcement Act 1994, all those who have committed an offence against minors must send an address notification form to local law enforcement officials each year. Those who are regarded as sexual predators must do this every 90 days. ${ }^{100}$

There is however a difference of opinion as to how long this registration requirement should last. The federal law has a 10 year time period. ${ }^{101}$ In New Jersey registration must continue for 15 years after release from prison. Ideally an offender should only have to register for a period of time during which he poses a real threat to the community. This is a question which is difficult to resolve in the sphere of sex offending. Another issue centres on how compliance with the registration requirements should be enforced and indeed in some states, non-compliance is treated as a felony offence. ${ }^{102}$ Effective enforcement in many states has proven difficult. In Washington for example, some studies suggest that only 50 per cent of offenders have registered. ${ }^{103}$ This creates injustice since it means only those offenders who actually abide by the law can be singled out for public exposure. These issues surrounding registration would have to carefully considered and dealt with by any New Zealand legislation in this area.

Perhaps the most comprehensive schemes incorporating a notification component are "Megan's Law" in New Jersey and Washington's Community Protection Act 1990. In Washington's statute, offenders are organised into three tiers based on their potential to offend again. ${ }^{104}$ Each tier has a different level of notification. The first tier includes all non-violent, first time offenders, whose victims have usually been a family member. In this case only the local police are notified of an offender's release. The second tier

100 Section 170101(b)(3).

$101 \quad 42$ USCA s14071(b)(6)(A).

102 Ariz Rev Stat Ann s13-3824(1989).

103 "Washington State Law Gets Mixed Reviews" Vancouver Sun, Vancouver, Canada, 2 February 1993, B4. 
includes first time rapists or child molesters, or individuals who have committed several less serious offences. In this case only local schools and community groups are notified.

The final tier contains individuals regarded as "sexual predators" because of their violent histories. Usually these individuals have vowed to strike again. It is only when these individuals are released into the community that the media and general community are informed. This targeting of information to specific interest groups is consistent with the reasoning in Hellewell and Paul $v$ Davis. Coddington's book makes no such distinctions and all offenders have their privacy right infringed to the same extent. Were New Zealand to adopt sex offender legislation it seems advisable that a tiered statute similar to Washington's be implemented.

Another important aspect incorporated into many notification laws is the opportunity offenders have for a hearing before identifying information is disseminated about them. In California for instance, hearings enable offenders to present evidence of reform. They may be pardoned from the registration and notification requirements after living only three years in the state. ${ }^{105}$ Coddington has failed to consider the possibilities that dissemination may detract from the rehabilitation process or may even simply be "needless" because the offender is no longer a threat. These possibilities should be recognised by any New Zealand legislative scheme. There may be compelling reasons why information about an offender should not be disseminated in individual cases, and the opportunity for a hearing is one way of providing the individual justice which Coddington's book lacks.

New Zealand's Police Minister Jack Elder has indicated any legislation dealing with sex offenders would probably follow British guidelines. ${ }^{106}$ As with United States legislation, the British Government appears to favour limited disclosure of paedophile's information on a case by case basis. An important difference from much of the American state law however is the unwillingness for Britain to have any general community notification at all. ${ }^{107}$ Thus, even if an offender was regarded as a sexual predator according to the third tier of the Washington Act, information would still only be released to specific community sectors. This not only reduces the risk of vigilantism but also reduces the risks of serious infringements on privacy. Were New Zealand to adopt legislation the option of general notification would also have to be considered. Along

\footnotetext{
105 Cal.Penal Code s4852.01(a).

106 Above $\mathrm{n} 99$.

107 "Plans for Paedophile Warnings Welcomed", The Dominion, Wellington, New Zealand, 12 August $1997,5$.
} 
with the issues surrounding registration and hearings for offenders such an option may have dangerous implications and should be fully debated before implementation.

\section{CONCLUSION}

There is a lack of evidence to suggest Coddington's publication is in "the legitimate public interest". Indeed the possibility of named offenders being driven "underground" may pose even greater threats to the community. This threat will be reduced if dissemination is more specific. If this was to occur then claims of a legitimate public interest would be more persuasive. However general dissemination will probably encourage more victims of sex crimes to seek justice. This does not outweigh the injustice of publishing a book on the assumption that all sex offenders are likely to offend again. For example, there appears to be no legitimate purpose in impinging on the privacy right of the offender (in the second scenario at the beginning of this article) to the same extent as the first. There are surely more effective and fairer ways of dealing with sex offending. The Kia Marama unit in particular is using techniques which have been successful overseas and appear to be successful in rehabilitating offenders in New Zealand also. Any measure which could impinge on this process should be viewed with suspicion.

There appear to be stronger public interests in knowing about those offenders who refuse rehabilitation although it is unclear whether notification of Coddington's type would prevent these individuals from reoffending. Indeed, before releasing information about any sex offender it seems reasonable that careful consideration should be given to the purpose such information would serve and the likelihood this purpose would be achieved. Coddington is unlikely to possess the requisite knowledge about each offender to ensure this occurs. It is only when such consideration is given by those who do possess such knowledge that an individual's right "to be let alone" can be legitimately set aside. 